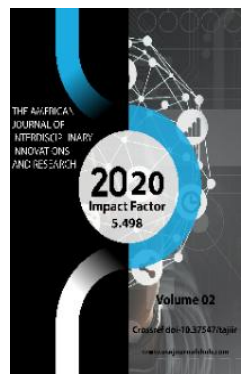

Journal Website: http://usajournalshub.c om/index,php/tajiir

Copyright: Original content from this work may be used under the terms of the creative commons attributes 4.0 licence.

\section{"Cluster" Theory And Its Peculiarities In Increasing The Competitiveness Of The Economy}

\author{
Khamidovna Khulkar Saidova \\ Bukhara Engineering Technological Institute, Bukhara, Uzbekistan \\ Kuliyeva Dilafruz Radjabovna \\ Bukhara Engineering Technological Institute, Bukhara, Uzbekistan \\ Djalolova Dilafruz Fattoxovna \\ Bukhara Engineering Technological Institute, Bukhara, Uzbekistan
}

\title{
ABSTRACT
}

In the article information like context of deepening economic reforms and modernization of the economy in our country, the formation of a competitive environment, increasing the competitiveness of industrial enterprises, the formation of industrial clusters play an important role in increasing industrial potential in the country and its regions are given.

\section{KEYWORDS}

International practice, world markets, educational development, international economic, geographical location.

\section{INTRODUCTION}

As the theory of regional competitiveness is still in its infancy, there are differing views and definitions among scholars on its content and understanding. In our opinion, the competitiveness of the region is to improve the living standards of the population through the organization of production of competitive 
goods and services, effectively using its competitive advantages.

In the implementation of the President's instructions "Priority should be given to the development and implementation of a program to increase the competitiveness of the economy," the main direction is the use of experience based on the theory of "Cluster" tested in international practice, including textile and plays an important role in the future of light industry.

The competitiveness of any country, region or region's economy is determined primarily by the competitiveness of its products in domestic and world markets. Reforms in the country's education system and all scientific, spiritual - The final indicator of educational development is also assessed by ensuring the competitiveness of our goods and services in modern markets.

The first in Uzbekistan A.Sh. Bekmurodov and Yang Son Belar "Development of the textile industry of Uzbekistan conducted research on the cluster approach to the strategy. Their research describes the use of clusters for economic development in foreign countries, the results of the information and communication in America, automotive, petrochemical and textile in Japan, ceramics and carpet production in Italy, the textile industry in the Republic of Korea.

At the same time, A.Sh. Bekmurodov and Yang Son Belar focused on the analysis of the export potential of the textile industry of Uzbekistan, developed scientific recommendations for attracting more foreign investment in the industry, and painted the product. The industrial zone cluster model was developed based on the experience in Daegu, the Republic of Korea.
The essence and factors of competitiveness of the country's economy.

No matter which model of economic development the countries of the world choose, the position and place of the country's economy in the world economy is determined by its level of competitiveness. International economic competition is the most important factor of technical progress, and under its influence, the process of continuous updating of production and management technologies will continue, the range of products will be updated and the quality will increase.

\section{MATERIALS AND METHODS}

Competitiveness is usually understood as the ability of commodity producers to produce for sale in a foreign market at a price that provides a minimum profitability. It should be noted that competitiveness is not limited to the commodity market, but has a macroeconomic character. Historically, the concept of competitiveness of countries is based on the theory of comparative advantages (cheap labor, rich natural resources, favorable geographical location, climate, infrastructure factors, etc.) that determine the place of the national economy in the international division of labor. Comparative advantages are given to the country by nature they are not eternal and cannot be reproduced. These competitive advantages are based on the development of science and technology, integration with production, globalization at the production level, and innovation at all stages, from production to delivery to the consumer. Uzbekistan has the following comparative advantages: 
- Availability of favorable natural and climatic conditions for agricultural development;

- Ownership of rich natural resources and recreational resources;

- Possession of a rich cultural and historical heritage allows the development of tourism; convenient geographical location of the country;

- Diligence of the population of Uzbekistan and availability of labor resources capable of entrepreneurship.

Analyzing the competitive advantages of Uzbekistan, we can distinguish:

- The stability of the political and legal system of the country;

- Large investments in human development (education, health, social needs);

- Average life expectancy:

- Competitiveness of labor resources;

- High level of education of the population of the country.

As mentioned above, in addition to having comparative advantages, it is necessary to develop the competitive advantages of the national economy. In this case, in order to increase the competitiveness of the economy, it is necessary to focus on the following factors, in particular: the stability of the political and legal system of the country, the competitiveness of labor and high education (3). Thus, the advantages in terms of competition are variable, the development of human capital is associated with innovative high technology, intelligence and is infinite in nature. It is necessary to clearly distinguish the comparative and competitive advantages of the country.
The integration of comparative and competitive advantages in a country enhances its competitiveness in the global economy. An important condition for ensuring the sustainable development of the world economy, the creation of international competition is determined by the openness of the world economy.

The liberalization of the Uzbek economy is deepening, the level of openness is increasing and its integration into the world economy is intensifying.

According to some economists, the degree of openness of the economy depends on the sectoral structure of national production. The higher the share of basic industries in the total output, the lower the level of economic openness. This situation is explained by the fact that the basic industries are less involved in the process of international specialization and are mainly focused on the domestic market.

It was noted that the openness of the economy is an important condition for international economic competition.

How is the competitiveness of countries determined and what does it depend on?

Why are some countries more competitive than others?

The concept of competitiveness is defined in the economic literature as the real and potential capabilities of firms in the design, manufacture and sale of goods according to the price and non-price characteristics of their competitors in the current environment.

Emphasizes that the creation of a conducive environment that ensures the success of

\section{RESULT AND DISCUSSION}


companies in the country depends on the following four important indicators (4):

- Availability of factors of production;

- Demand indicators;

- Nearby and service networks;

- Competitive environment and firm strategy.

The effective operation of national companies in this environment determines the competitiveness of the country. In world practice, experts use more than 340 indicators and more than 100 methods to determine the competitiveness of the national economy.

The following are the main factors in determining the competitiveness of a country:

- Economic potential and economic growth rates;

- Efficiency of industrial production;

- The level of development of scientific and technical progress and the pace of its development;

- Participation in the international division of labor; domestic market size and dynamics;

- The role of the economic state; -flexibility of the financial system;

- Availability of labor resources and level of qualification;

- Domestic political and socio-economic situation;

\section{CONCLUSION}

The level and ability of the economy to adapt to the demands of the world market. One of the international studies analyzing the competitiveness of countries is the methodology of the World Economic Forum. In the process of research, aggregate indices of competitiveness are based on important macro and microeconomic indicators that characterize the dynamics of medium and long-term development in assessing the economic growth of the country. Assessing a country's competitiveness involves calculating competitiveness indicators based on key factors based on the collection, grouping, and aggregation of a large amount of data. Then there are aggregate indices and sub-indices that reflect the contribution of all factors to the competitiveness index.

\section{REFERENCES}

1. M.Porter Competition. / Per. s angl. - M.: Izdatelskiy dom "Williams". 2002. S. 176.

2. R.O. Alimov, A.F. Rasulev et al. Problems of increasing the competitiveness of the Uzbek economy: theory and practice. S.S. Edited by Gulyamov. -T.: Konsauditinform - Nashr, 2006. 26b.

3. E.Betextina World practice of formation of scientific - technical policy. Kishinev, $2000 \mathrm{~g}$ 